\title{
Ischemic Evidence Type
}

National Cancer Institute

\section{Source}

National Cancer Institute. Ischemic Evidence Type. NCI Thesaurus. Code C119236.

A classification or description of the evidence of ischemia in the subject. 